\title{
Strength Properties of Hardwood Timber Species Exposed to Decay and Marine Borer Attack in Tidal Zones
}

\author{
Jeffrey Lynes ${ }^{1}$, Iraj H.P. Mamaghani² \\ ${ }^{1}$ Graduate Student, Department of Civil Engineering, University of North Dakota \\ Grand Forks, ND 58201, USA \\ jeffrey.lynes@und.edu; iraj.mamaghani@und.edu \\ ${ }^{2}$ Associate Professor, Department of Civil Engineering, University of North Dakota \\ Grand Forks, ND 58201, USA
}

\begin{abstract}
The Pinaceae family of timber displays sound strength qualities in underground or dry conditions, with good strength in compression parallel to the grain that make them ideal for use as piles. However, they decay rapidly in marine environments, due to low heartwood rot resistance and large radius of sapwood that is susceptible to attack by marine borers and rot. Therefore, preservative treatment of Pinaceae is the standard practice for producing rot resistant timber marine piles in the U.S. While it has been shown that hardwoods can be marginally treated with preservatives, decay evaluations are primarily based on ground contact and lack inspection of post-decay strength properties.

This paper describes the ongoing research to chemically treat and evaluate the heartwood of four naturally rot-resistant timber families available in the U.S. for use as marine timber: Black locust, white oak, black walnut, and swamp mahogany. Small clearheartwood samples will be treated with oil-borne preservatives that have already shown better decay protection for red oak over Pinaceae family. The specimens will be sampled annually over the course of a decade in estuary saltwater and tested for decay, marine borer infestation and mechanical properties. Specifically, specimens will be differentiated by exposure in three different zones for comparison to realistic exposure scenarios of a structure: continuous submersion underwater, within the tidal zone for cyclical water and air exposure, and in the splash zone with minimal water exposure. Treated samples will be compared to untreated and preservative treated control specimens of the most common Pinaceae species, loblolly pine, and each hardwood species. This will enable treatment comparison to the industry standard (Pinaceae) and treatment comparison within a species. The objectives of this study are twofold: To establish correlation between rate of decay and strength properties in marine timber, and to determine the viability of treating U.S. hardwoods for use as marine timbers.
\end{abstract}

Keywords: Marine, timber, hardwood, strength, moisture, rot, resistance, borer.

\section{Introduction}

\subsection{Structure of Wood}

Softwood timber is the primary wood class used for production of structural wood and is common in marine structures. In the U.S., the softwood loblolly pine (Pinus taeda) is the most widely harvested timber and favored for its straight form, rapid growth, and high strength properties in compression. [1]. While pine has a satisfactory structure at harvest, the rot-susceptible heartwood is also quickly attacked by marine borers in a saltwater environment if the sapwood is not treated. Even with high volume of treatment, any penetration of the treated sapwood opens a pathway for marine borers to attack the susceptible heartwood. The structural difference between softwoods and hardwoods is at the cellular level. Softwoods have only parenchyma and tracheids, while hardwoods additionally have vessels which provide good conductivity and fibers which provide good support [1], as shown in Figures 1 and 2. Hardwood species also vary in thickness of fiber walls and Figure 3 shows that black locust, one of the hardest North American timber species, has very thick fiber walls. Sapwood typically ranges in thickness by species and growing conditions with vigorous trees having widest radii of sapwood and hardwoods usually displaying smaller radii of sapwood, although no timber species has decayresistant sapwood. Conversely, heartwood is made of entirely inactive cells with extractives that in some species create fungi and insect resistivity. Some species, such as white oak, also have heartwood vessels that are sealed or plugged with ingrowths called tyloses, which prevent passage of liquids through the vessels [1]. The presence of tyloses is advantageous in reducing the rate of rot or borer infestation in wood, but it also makes for difficult penetration of preservative treatment. 


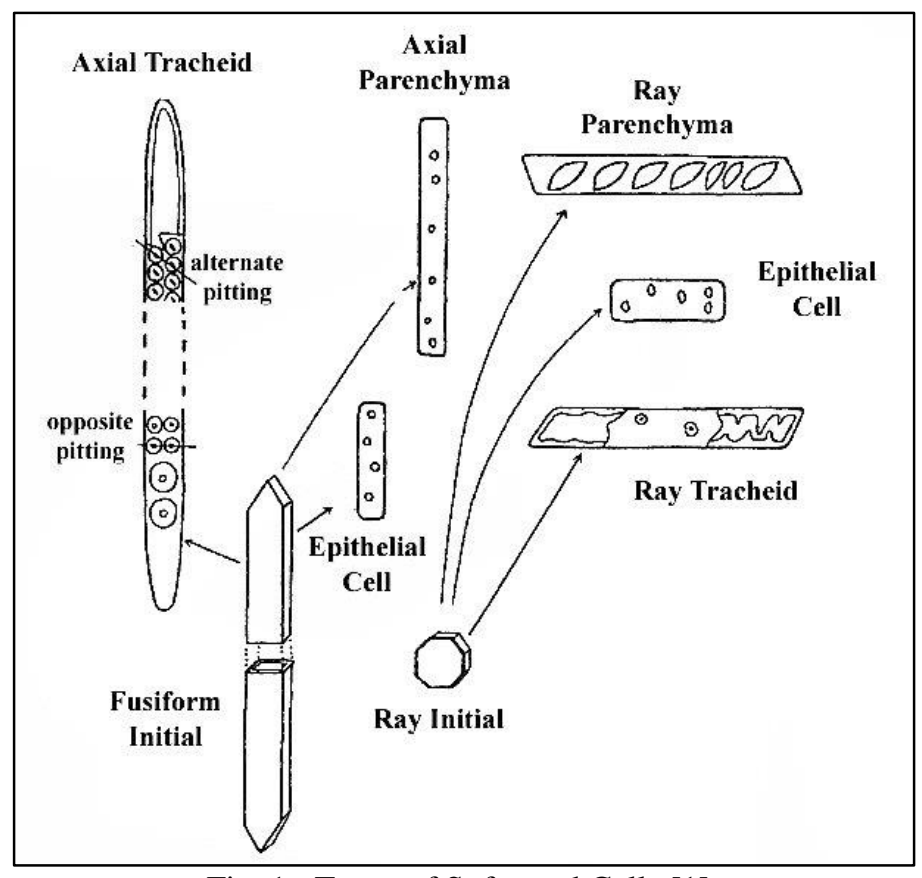

Fig. 1: Types of Softwood Cells [1].

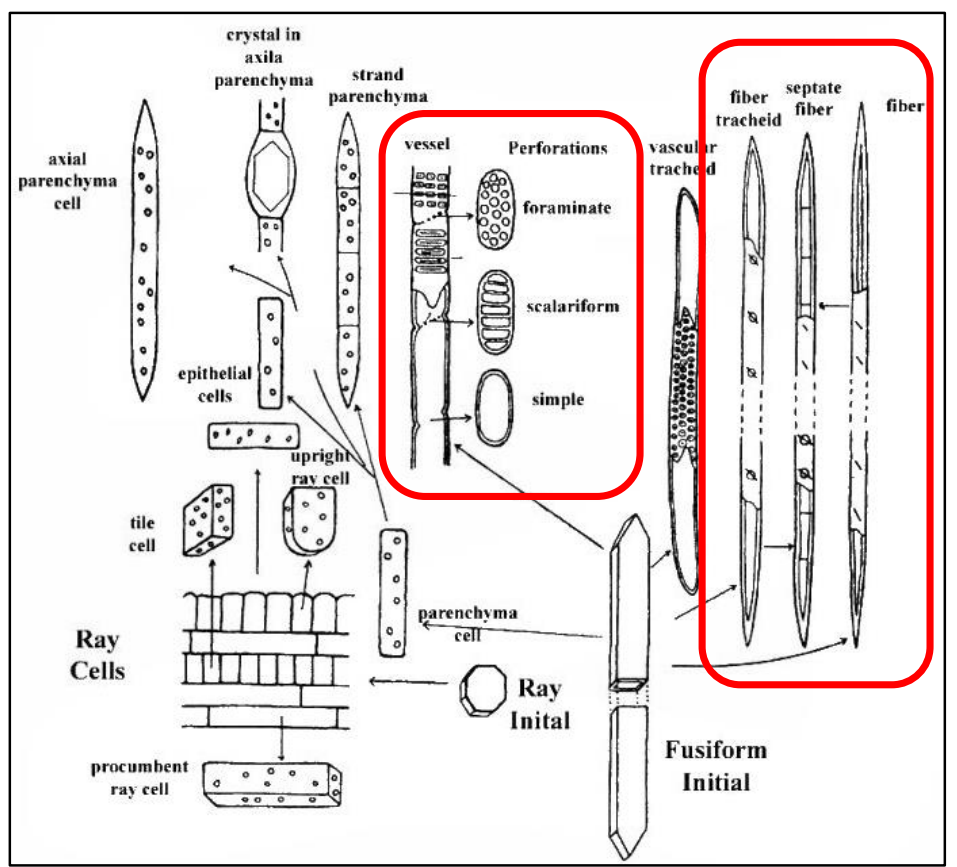

Fig. 2: Types of Hardwood Cells [1].

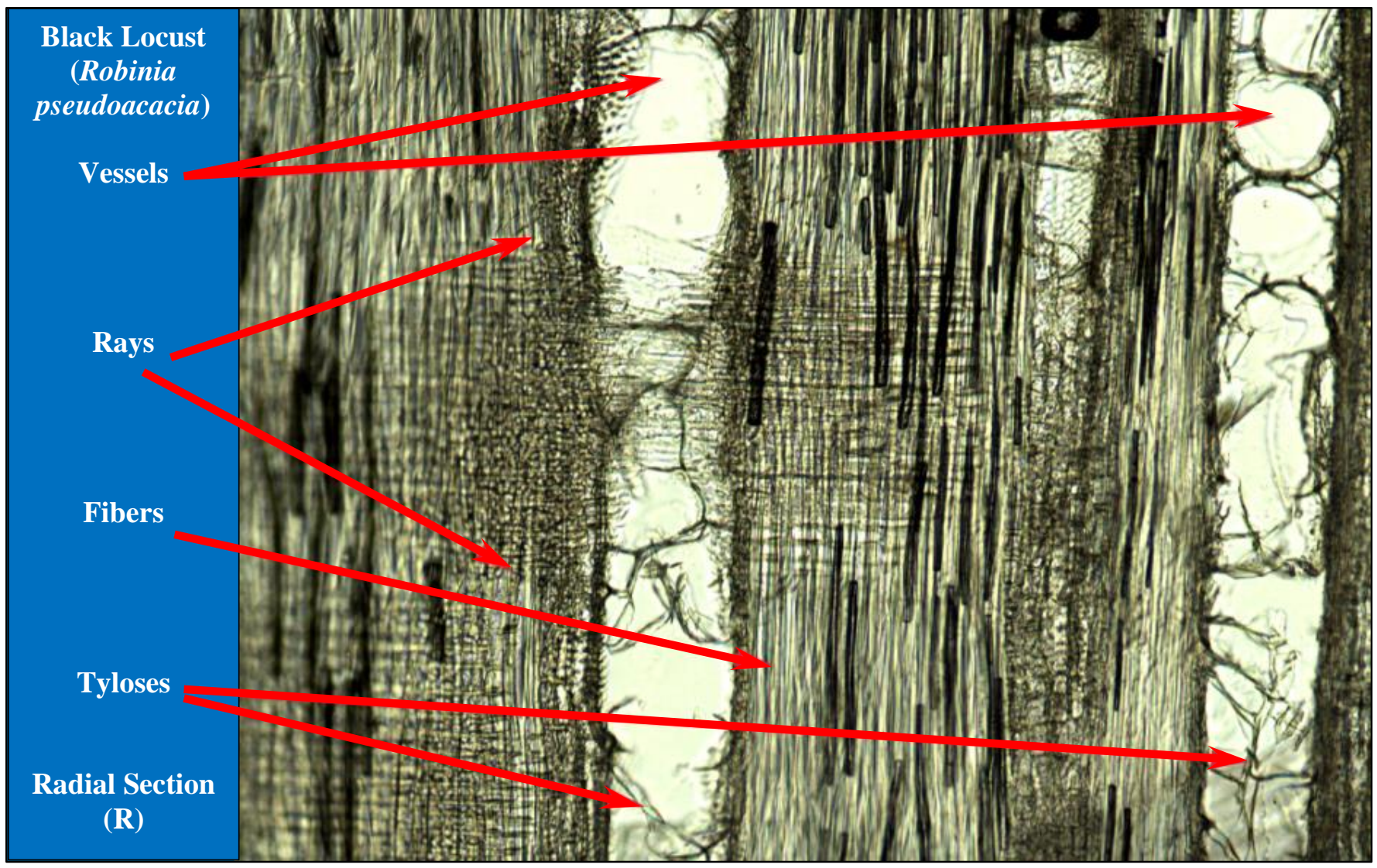

Fig. 3: Microscopic View of Cell Types and Tyloses in Black Locust [1]. 


\subsection{Marine Borers}

Marine borers account for the most widespread destruction of wooden marine structures. They are classified as either mollusks, of which families Teredinidae and Pholadidae common to the U.S., or crustaceans of which Limnoria, Sphaeroma, and Chelura are the most destructive genera [2]. The mollusk class burrow deepest into the interior of timber with little evidence to denote their presence except for pinholes on the wood surface. Crustacean class are more easily observed, and their destruction is to the outer wood layers first then further toward the center. All marine borers thrive in waters with practical salinity units (PSU) between 9.5 and 35, which equate to $0.95 \%$ and $3.5 \%$ salinity [3]. It is expected that Teredinidae and Limnoria will be the primary attackers of specimens in this study.

A sudden drop from a higher state of salinity to lower state typically incites spawning of marine borers [4]. Since salinity cannot be controlled, it remains that preventing settlement of borer larvae is a key objective of any longevity plan for timber marine piles. Barriers work well against marine borers until broken, degraded, cracked, etc. at which time the borers can make entry while preventing inspection of the piles for extent of damage. Even an underwater coating may prevent larvae attachment only until a check or split develops in the pile, creating a break in the coating barrier. Concrete encasement is widely used although is an expensive option for prevention of marine borers as the encasement must extend from below the mudline to above the tidal zone. However, over time concrete encasements eventually crack, producing an entry path for the borers to the heartwood. For these reasons it is important to not just have a surface treatment against marine borers, but also a timber material that can mitigate their persistent attack.

\subsection{General Strength Properties of Wood for Testing}

The four hardwood species chosen for this study are black locust (Robinia pseudoacacia), white oak (Quercus alba), black walnut (Juglans nigra), and swamp mahogany (Eucalyptus Robusta). They display high rot resistance and at least one characteristic of high extractive content, presence of tyloses or very dense heartwood and are true hardwoods in the sense that they have higher strength properties than loblolly pine for almost every category of both green and kiln-dry conditions. Table 1 is a summary of the most common design strength properties [5] for the wood species that will be tested, with values represented at green and kiln-dry moisture content. Table 1 will act as the comparison database for all results of strength testing in this study. There are incomplete fields for Eucalyptus Robusta in the table and therefore the associated eucalyptus tests will be compared to the other species.

Table 1: General Strength Properties of Wood for Testing [6], [7].

\begin{tabular}{|c|c|c|c|c|c|c|}
\hline $\begin{array}{l}\text { Species } \\
\text { Name }\end{array}$ & $\begin{array}{c}\text { Moisture } \\
\text { Content }\end{array}$ & $\begin{array}{l}\text { Static bending } \\
\text { Modulus } \\
\text { of Rupture } \\
(\mathrm{kPa})\end{array}$ & $\begin{array}{l}\text { Impact } \\
\text { Bending } \\
\text { (mm) }\end{array}$ & $\begin{array}{l}\text { Com- } \\
\text { pression } \\
\text { Parallel } \\
\text { to Grain } \\
(\mathrm{kPa})\end{array}$ & $\begin{array}{l}\text { Com- } \\
\text { pression } \\
\text { Perpen- } \\
\text { dicular } \\
\text { to } \mathrm{Grain} \\
(\mathrm{kPa})\end{array}$ & $\begin{array}{c}\text { Shear } \\
\text { Parallel } \\
\text { to } \\
\text { Grain } \\
(\mathrm{kPa})\end{array}$ \\
\hline \multirow[t]{2}{*}{ Pine, Loblolly } & Green & 50,000 & 760 & 24,200 & 2,700 & 5,900 \\
\hline & $12 \%$ & 88,000 & 760 & 49,200 & 5,400 & 9,600 \\
\hline \multirow[t]{2}{*}{ Locust, Black } & Green & 95,000 & 1,120 & 46,900 & 8,000 & 12,100 \\
\hline & $12 \%$ & 134,000 & 1,450 & 70,200 & 12,600 & 17,100 \\
\hline \multirow[t]{2}{*}{ Oak, White } & Green & 57,000 & 1,070 & 24,500 & 4,600 & 8,600 \\
\hline & $12 \%$ & 105,000 & 940 & 51,300 & 7,400 & 13,800 \\
\hline \multirow[t]{2}{*}{ Black Walnut } & Green & 66,000 & 940 & 29,600 & 3,400 & 8,400 \\
\hline & $12 \%$ & 101,000 & 860 & 52,300 & 7,000 & 9,400 \\
\hline \multirow[t]{2}{*}{ Eucalyptus, Robusta } & $88 \%$ & 71,700 & - & 36,300 & - & - \\
\hline & $12 \%$ & 107,600 & - & 56,500 & - & - \\
\hline
\end{tabular}

\subsection{Applicable Findings from Other Tests and Procedures}

One study of completely immersed heartwood blocks of Malaysian hardwoods concluded that wood species with high extractive content were more resistive to marine borers [8], confirming a finding by Borges et al. in 2008 that Limnoria digestion is disrupted by natural timber extractives. Findings of the study also indicated higher wood density correlates to 
less marine borer destruction, as measured by number of borer holes. The study, as well as many others, successfully identified species of wood that are resistant to marine borer attack but did not include measurement of the strength properties after exposure to marine borers. In contrast, this study will not only identify which hardwoods are more mitigant to marine borer decay but also measure how well they perform over time.

The Marine Wood Maintenance Manual [9] addresses prevention of marine borer attack to timber piles of Douglas fir that can be correlated to other timber species as well. One finding is that piles of the extremely dense tropical hardwood Greenheart failed after only 8 years of exposure along the Oregon coast because they contained unresistant sapwood. Marine borers first attached in the sapwood and from there were able to directly attack the heartwood. The manual suggests that marine borers have limited ability to establish directly on heartwood-only piles. Additionally, Wang and De Groot identified the transition zone as having a probable tradeoff between permeability of sapwood and durability of heartwood and concluded that research in such an important area as the transition zone is lacking [10]. Even so, it is desirable that clear-wood specimens for this study contain only heartwood to confirm or invalidate the possibility that heartwood poses problems for marine borer attachment.

Preservation methods affect timber species differently due to penetration and distribution of the preservative. Sapwood of softwoods can be pressure treated and it is important in round timber piles to create a treated zone around the heartwood if sapwood is intact. Heartwood is treatable in most timber species and even some hardwoods have reasonable ease of heartwood penetration, such as red oak [11]. The Wood Handbook lists the typical resistance of heartwood penetration by timber species, but only two (2) of the rot-resistant timber species proposed for this study are listed: Black locust and white oak, both of which have heartwood that is very difficult to penetrate with preservative. (The other two rot-resistant species chosen for this study; black walnut and swamp mahogany, are not considered for preservative treatment in the Wood Handbook.) Incising up to $19 \mathrm{~mm}$ deep is used to increase penetrant reception of piles and effectively improves heartwood penetration. However, incising also reduces strength significantly because it opens cell lumens parallel to the grain [11]. Two main categories of treatment are pressure (vacuum) and non-pressure (dipping, steeping, and diffusion). Lebow recommends use of the highly effective pressure treatment processes over non-pressure treatment [11], which is the process Laks et al. also used pressure processes for their treatment of regional U.S. hardwoods such as northern red oak, tulip poplar and cottonwood [12].

The ASTM D2555-17a lists external factors that should be used in converting clear-wood specimen strengths to design values for timber: Duration of load, moisture content, temperature, and strength-reducing characteristics. Of these, only moisture content is environmentally adverse to wood with an inability to control (temperature ranges along the coasts of mainland U.S. are not damaging to wood) and must therefore be evaluated for effects on field strength of each timber species. Since the strength of wood increases as the moisture content decreases below the fiber saturation point of 30 percent, strength values of wood are given for both the green condition and kiln dry standard of $12 \%$ moisture content [13], as shown in Figure 1. The general relationship between moisture content and selected strength properties is depicted in Figure 4. Note that the moisture relationship to shear parallel to grain is not represented in Figure 4.

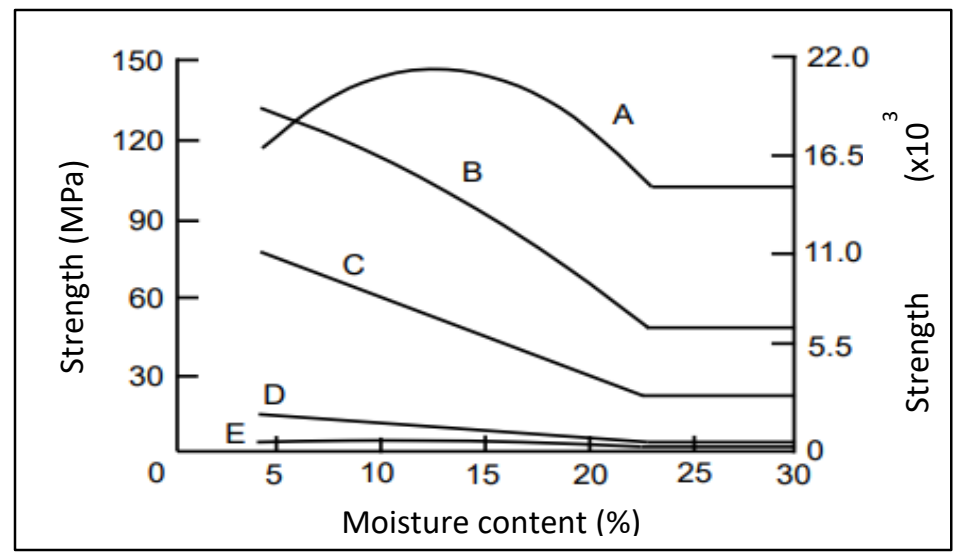

Fig. 4: Effect of Moisture Content on Wood Strength Properties [6]. A is tension parallel to the grain; $\mathrm{B}$, bending; $\mathrm{C}$, compression parallel to the grain; $\mathrm{D}$, compression perpendicular to the grain; and $\mathrm{E}$, tension perpendicular to the grain. 
From the green and 12\% moisture values of a given timber species an empirical relationship exists for finding a strength property at any moisture level below the fiber saturation point (the point at which strength properties of wood begin declining). For ambient temperature of $21^{\circ} \mathrm{C}$ most strength properties of wood can be found for the field moisture content to be:

$$
P=P_{12}\left(\frac{P_{12}}{P_{g}}\right)^{\left(\frac{12-M}{M_{p}-12}\right)}
$$

where $P$ is the strength property at moisture content $M(\%), P_{12}$ the same property at $12 \%$ moisture content, $P_{\mathrm{g}}$ the same property for green wood, and $M_{\mathrm{p}}$ is the moisture content at the intersection of a horizontal line representing the strength of green wood and an inclined line representing the logarithm of the strength-moisture content relationship for dry wood [6]. For loblolly pine, the $\mathrm{M}_{\mathrm{p}}$ value is 21 and all hardwood species in this study can be assumed to have an $\mathrm{M}_{\mathrm{p}}$ value of 25 per the Wood Handbook.

What is not well known for timber species is how subsequent increase of moisture in the field affects the strength and modulus of elasticity properties of previously dried wood. An even more important unknown factor for wood used in marine construction is how repeated wetting and drying affects the strength and modulus of elasticity, such as is encountered daily near tidal zones. In fact, a single marine pile or brace may be exposed to three unique field moisture conditions along its length: Complete saturation in the submerged zone below mean lower low water (MLLW), daily wet and dry cycles within the tidal zone, and typically dry condition with occasional moisture exposure in the splash zone above mean higher high water (MHHW). The ASTM D2555-17a includes tables of ratios for converting dry wood to equivalent green wood strength properties by species, but those ratios are not applicable to the marine environment. It is therefore important that each clear-wood specimen be evaluated for their strength properties after exposure to realistic field moisture conditions and the results compared to Equation (1).

\section{Methods}

The strength properties of specimens will be evaluated over the course of a decade and categorized by timber species, percent section remaining from marine borer attack, location in exposure zones, and percent moisture content.

\subsection{Selection of Specimens}

To reduce variations of fiber strength within a species, specimens will be cut to procure moderately sized growth bands from heartwood. A minimum of three (3) treated specimens by species will be exposed to the submersion and splash zones, as well as three (3) untreated specimens by species for controls. During daily tidal cycles, wood exposed in the top of the tidal zone will be exposed to the atmosphere for a longer period than that in the bottom of the tidal zone. To account for such a difference of moisture exposures in the same zone, doubling the sample size to six (6) per treated species and six (6) per control species in the tidal zone is warranted. The sum of required samples per annual strength test will therefore be 120 , with five separate tests requiring a total of 600 specimens per annum. Initially, three (3) specimens of every species combination will be tested so that 30 specimens will act as the base comparison. For the tests to continue over the course of a decade, 1,206 specimens of each species will be required for a total of 6,030 small clear-wood specimens.

\subsection{Treatment}

This study will primarily test hardwood timber species strength performance during degradation as compared to the industry standard of Southern Pine. It is not intended to identify effective types of preservative treatments or combinations thereof. Hence, only one preservative treatment will be used for this study based on findings of previous research. Of many varieties of chemical treatments tested, oil-borne treatments perform best in hardwood species [12]. As the industry standard for chemical treatment, the water-borne preservative chromated copper arsenate (CCA) displays only average volume uptake in hardwoods with average volume retention over time. By comparison, creosote has the lowest volume uptake on average by hardwoods, yet it is retained longer in red oak than in all southern yellow pine species [12]. For this reason, creosote will be used as the preservative of choice, with the expectation that after a decade the trend of volumetric retention between test specimens and control specimens of loblolly pine will begin converging. Due to the success of 
hardwood treatability in the Laks et al. evaluation [12], the same treatment procedures will be duplicated for this study with one (1) adjustment in the procedure: Following the primary vacuum and pressure cycles, an additional 10-minute vacuum cycle and 60-minute pressure cycle will be added to temporarily relieve cell pressure for better penetration. The following steps summarize the specimen chemical treatment procedure.

1) Cut heartwood-only specimens according to quantities listed in Section 2.1 and according to sizes in Table 2.

2) Condition specimens by exposing to ambient room temperature and humidity for three (3) months.

3) Weigh and measure each specimen and record.

4) Immerse specimens in metal tanks filled with creosote and place in a treating cylinder, then apply a vacuum of $17.3 \mathrm{kPa}$ for 30 minutes followed by pressurization of $790 \mathrm{kPa}$ for one (1) hour.

5) Apply a vacuum of $17.3 \mathrm{kPa}$ for 10 minutes followed by pressurization of $790 \mathrm{kPa}$ for one (1) hour.

6) Return specimens to atmospheric pressure and leave in creosote solution for an additional 10 minutes to achieve equilibrium.

7) Blot-dry specimens, weigh, measure, then dry in ambient conditions for three (3) months.

\subsection{Potential Field Sites}

Field sites must meet the criteria of being in tidal areas with a minimum practical salinity unit (PSU) of 9.5 yearround to allow for uninterrupted marine borer attack [3]. Figure 5 shows the average salinity zones of Pamlico Sound in North Carolina are acceptable [14], as well as the southern half of the Chesapeake Bay in Maryland as displayed in Figure 6 [15]. Ideally, sites will have access via roadway so that specimens can be easily examined and collected. Sites should also be protected from direct ocean wind and waves to better control the exposure zones on the racks. Lastly, ideal sites will be located near a water recording station for backup access to water temperature and salinity data collection.

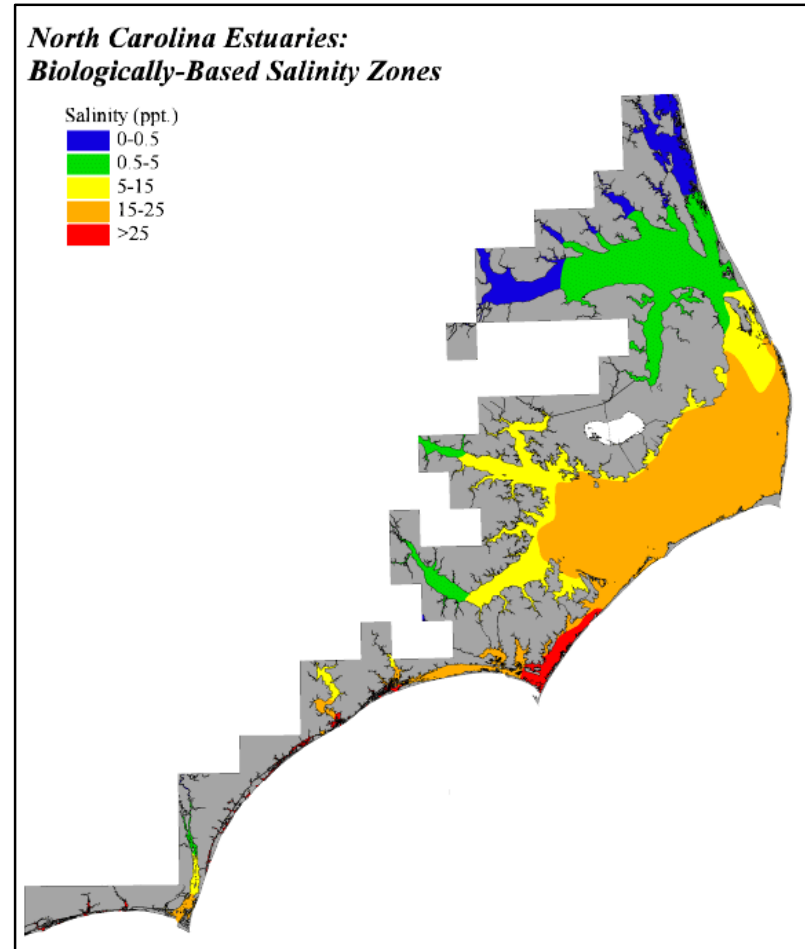

Fig. 5: PSU Range for Pamlico Sound [14].

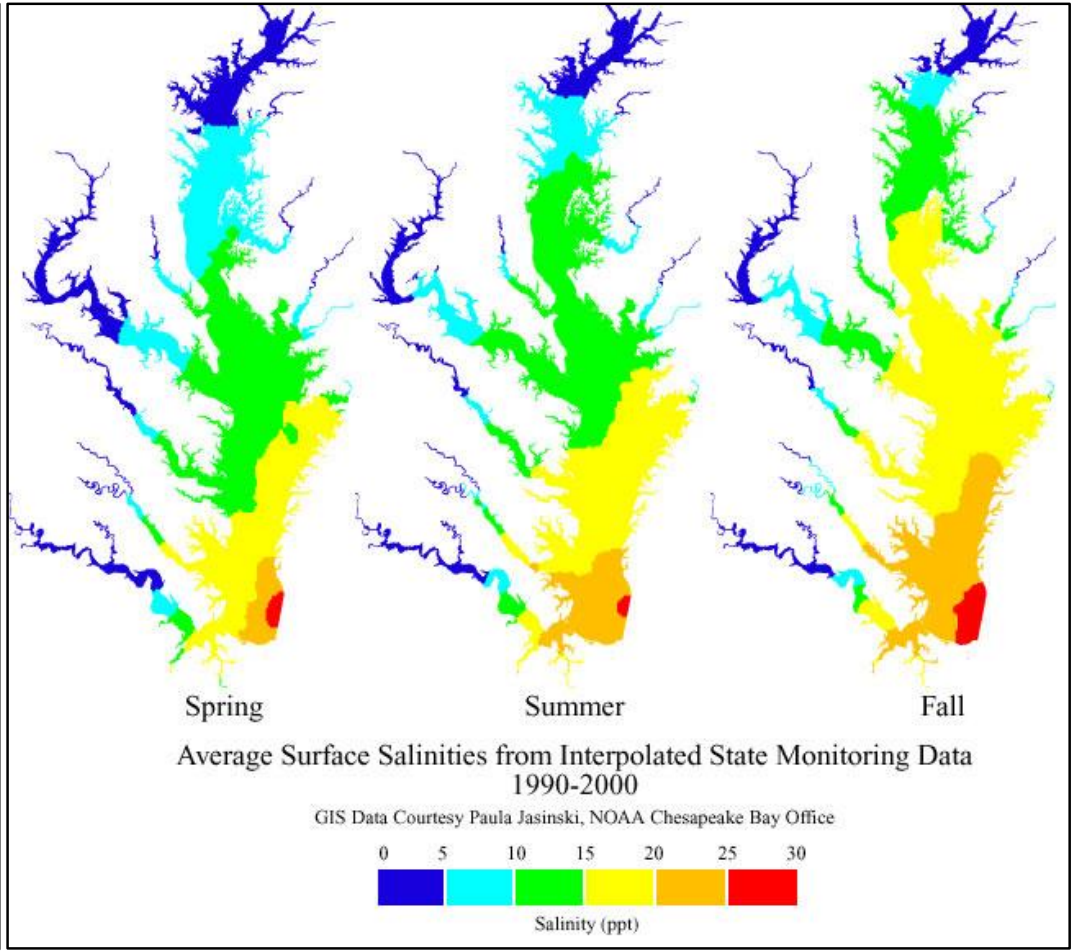

Fig. 6: PSU Range for Chesapeake Bay [15]. 


\subsection{Field Array of Specimens}

Each specimen will be tracked by rack location following initial measurements of treatment solution uptake. The specimens will be grouped on racks by year of sampling (120 per rack and five (5) racks per year) to simplify the collection process and enable visual comparison between wood species for photographic documentation. The racks must be anchored and fixed vertically to ensure specimen groups remain within their assigned zones. Temperature gauges will be attached to one (1) rack of each year group at the top and bottom to ensure the widest range of temperatures experienced by the specimens are recorded. One (1) salinity gauge will be attached in the submersion zone to each rack containing a temperature gauge. Photographs will be taken of each rack at initial setup and after the assigned exposure period. Vertical heights of rack positions in relation to NAVD-88 will be recorded at initial setup and before removal.

\subsection{Strength Testing}

Following treatment and the three-month drying period, three (3) treated and untreated specimens of each species will be tested for baseline strength properties. All other strength tests will be conducted annually in a period no less than 11 months and no greater than 13 months. The annual 600 specimens for testing will be kept as close to field moisture condition (saltwater) as possible through testing at the lab. The test procedures in Table 2 will be followed in the lab to record the actual wood strength values listed in Table 1.

Table 2: ASTM Test Procedures for Specimens [16].

\begin{tabular}{|c|c|c|c|c|c|c|}
\hline & $\begin{array}{c}\text { Moisture } \\
\text { Content }\end{array}$ & $\begin{array}{c}\text { Modulus } \\
\text { of } \\
\text { Rupture }\end{array}$ & $\begin{array}{c}\text { Impact } \\
\text { Bending }\end{array}$ & $\begin{array}{c}\text { Compression } \\
\text { Parallel to } \\
\text { Grain }\end{array}$ & $\begin{array}{c}\text { Compression } \\
\text { Perpendicular } \\
\text { to Grain }\end{array}$ & $\begin{array}{c}\text { Shear } \\
\text { Parallel } \\
\text { to Grain }\end{array}$ \\
\hline ASTM Standard & D143-14 & D143-14 & D143-14 & D143-14 & D143-14 & D143-14 \\
\hline Length & varies & $760 \mathrm{~mm}$ & $760 \mathrm{~mm}$ & $200 \mathrm{~mm}$ & $150 \mathrm{~mm}$ & $63 \mathrm{~mm}$ \\
\hline Width & varies & $50 \mathrm{~mm}$ & $50 \mathrm{~mm}$ & $50 \mathrm{~mm}$ & $50 \mathrm{~mm}$ & $50 \mathrm{~mm}$ \\
\hline Height & varies & $50 \mathrm{~mm}$ & $50 \mathrm{~mm}$ & $50 \mathrm{~mm}$ & $50 \mathrm{~mm}$ & $50 \mathrm{~mm}$ \\
\hline
\end{tabular}

\subsection{Evaluation}

Treatment retention will be compared by a ratio of treatment volume per specimen to clear-wood specimen volume. Statistical analysis will be completed by Analysis of Variance (ANOVA) using the General Linear Model (GLM) which simultaneously accounts for multiple linear regression models, and Tukey Procedure. Independent variables will include timber species, percent section remaining from marine borer attack (measured photometrically), exposure zone, and moisture content.

\section{Expected Results}

It is expected that the black walnut samples will have the least variances in strength properties over time. This is anticipated due to their expected higher creosote penetration from relatively lower heartwood density, as well as the high concentration of extractives in the heartwood, causing disruption to persistent marine borer attack. It is also expected that throughout the ranges of tidal exposure, all hardwood specimens will retain strength properties closer to initial values than that of loblolly pine. Lastly, I anticipate there will be an inverse relationship between regular exposure to field moisture and strength properties of specimens.

\section{Conclusion}

While timber use for marine structures has declined with continuous advances in high strength steel, reinforced concrete, and composites, it continues to be used for construction of new marine structures due to its low cost, simplicity, and widespread availability [12]. Without understanding the effects of marine borers and rot on the strength of timbers, the design strength properties of a given timber species may poorly reflect true conditions in a marine environment. The results of this study will help determine the feasibility of heartwood-only piles as a long-term solution in mitigating marine borer attack and reducing rates of decay over time. 


\section{References}

[1] H. Alden, "Wood and Charcoal Identification in Southern Maryland," Jefferson Patterson Park and Museum, State $\begin{array}{lllll}\text { Museum of } & \text { Archaeology, } & 2009 & \text { Anline]. }\end{array}$ apps.jefpat.maryland.gov/woodandcharcoalid/WoodAndCharcoal-Part2.htm

[2] M. Castagna, "Shipworms and Other Marine Borers," U.S. Fish and Wildlife Service, Fishery Leaflet 505, June 1961 [Online]. Available: https://spo.nmfs.noaa.gov/sites/default/files/legacy-pdfs/leaflet505.pdf

[3] D. Jones, C. Brischke, "Performance of Bio-based Building Materials." Editor: E. Suttie, Elsevier, Ltd., 2017, Pages 384-481 [Online]. Available: https://doi.org/10.1016/B978-0-08-100982-6.00007-0

[4] S. K. Pati, V. Rao Malladi, M. Balaji, and D. Swain, "Deterioration of Wood by Marine Borers in a Tropical Harbour: Influence of Environmental Parameters and Biotic Factors," International Journal of Marine Science, Vol. 4, No. 13: 119-133, 2014 [Online]. Available: https://www.researchgate.net/publication/272087717 Deterioration of Wood by Marine Borers in a Tropical Harbour Influence of Environmental Parameters and Biotic Factors

[5] S. V. Glass and S. L. Zelinka, "Wood Handbook, Chapter 04: Moisture Relations and Physical Properties of Wood," General Technical Report FPL-GTR-190. Madison, WI: U.S. Department of Agriculture, Forest Service, Forest Products Laboratory: 4-1 - 4-19. Chapter 4, 2010.

[6] D. E. Kretschmann, "Wood Handbook - Wood as an Engineering Material," Forest Products Laboratory General Technical Report 190, 2010, Chpt. 5 (Mechanical Properties of Wood).

[7] R. G. Skolmen, "Robusta Eucalyptus Wood: Its Properties and Uses," U.S. Forest Service Research Paper PSW-9: 1963 [Online]. Available: https://www.fs.fed.us/psw/publications/documents/psw_rp009/psw_rp009.pdf

[8] K. Roszaini, K. and U. Salmiah, "Resistance of Five Timber Species to Marine Borer Attack," Journal of Tropical Forest Science, Vol. 27, No 3: 400-412, 2015 [Online]. Available: https://www.researchgate.net/publication/ 289999129_Resistance_of_five_timber_species_to_marine_borer_attack

[9] J. Morrell, G. Helsing, R.D. Graham, "Marine Wood Maintenance Manual: A Guide for Proper Use of Douglas-Fir in Marine Exposures," Oregon State University Forest Research Lab, Research Bulletin 48, October 1984.

[10] J. Z. Wang and R. De Groot, "Treatability and Durability of Heartwood," Forest Products Laboratory, General Technical Report-94 (pages 252-260), Madison, WI, 1996 [Online]. Available: https://www.fpl.fs.fed.us/documnts/pdf1996/ wang96b.pdf

[11] S. T. Lebow, "Wood Handbook - Wood as an Engineering Material," Forest Products Laboratory General Technical Report 190, 2010, Chpt. 15 (Wood Preservation).

[12] P. E. Laks, K.W. Gutting, and J. B. Pickens, "Field Performance of New Wood Preservative Systems in Secondary Timber Species," Forest Products Laboratory, General Technical Report-94: 1997, pp. 398-400 [Online]. Available: https://www.fpl. fs.fed.us/ documnts/pdf1996/laks96a.pdf

[13] ASTM D2555-17a, "Standard Practice for Establishing Clear Wood Strength Values," ASTM International, West Conshohocken, PA, 2017, www.astm.org

[14] NOAA/SEA Division, "North Carolina Estuaries: Biologically-Based Salinity Zones," Prepared for South Atlantic Fishery Management Council, January 1998.

[15] Maryland Department of Natural Resources, "Annual Mean Salinity Map," Eyes on the Bay / Eyes on Salinity Lesson Plan, 2000 [Online]. Available: http://eyesonthebay.dnr.maryland.gov/eyesonthebay/img/bay_salinity.jpg

[16] ASTM D143-14, "Standard Test Methods for Small Clear Specimens of Timber," ASTM International, West Conshohocken, PA, 2017, www.astm.org 